\title{
Chemically Bonding of Amantadine with Gardenamide A Enhances the Neuroprotective Effects against Corticosterone-Induced Insults in PC12 Cells
}

\author{
Jiaqiang Zhao ${ }^{1, \dagger}$, Lizhi Peng ${ }^{1, \dagger}$, Wenhua Zheng ${ }^{2, *}$, Rikang Wang ${ }^{3, \dagger}$, Lei Zhang ${ }^{1}$, Jian Yang ${ }^{1}$ \\ and Heru Chen $1,4, *$
}

1 Institute of Traditional Chinese Medicine and Natural Products, College of Pharmacy, Jinan University, Guangzhou 510632, China; E-Mails: jqzhaodzs@163.com (J.Z.); 15900088863@163.com (L.P.); 13247377339@163.com (L.Z.); 13187048948@163.com (J.Y.)

2 Faculty of Health Sciences, University of Macao, Taipa, Macao, China

3 National Pharmaceutical Engineering Center for Solid Preparation in Chinese Herbal Medicine, Jiangxi University of Traditional Chinese Medicine, Nanchang 330006, China;

E-Mail: wrk168ok@163.com

4 Guangdong Province Key Laboratory of Pharmacodynamic Constituents of TCM and New Drugs Research, Guangzhou 510632, China

$\dagger$ These authors contributed equally to this work.

* Authors to whom correspondence should be addressed;

E-Mails: Wenhuazheng@umac.com (W.Z.); thrchen@jnu.edu.cn (H.C.);

Tel.: +853-8822-4919 (W.Z.); +86-20-3837-5299 (H.C.);

Fax: +853-8822-2314 (W.Z.); +86-20-8522-1559 (H.C.).

Academic Editor: Maurizio Battino

Received: 25 July 2015 / Accepted: 6 September 2015 / Published: 21 September 2015

\begin{abstract}
Two amantadine (ATD)-gardenamide A (GA) ligands have been designed and synthesized. The bonding of ATD with GA through a methylene carbonyl brigde (L1) enhances the neuroprotective effect against corticosterone (CORT)-induced impairments in PC12 cells; while the bonding through a succinyl brigde (L2) does not. L1 reduces the level of reactive oxygen species (ROS) and cell apoptosis generated by CORT. It restores CORT-changed cell morphology to a state that is closed to normal PC12 cells. One mechanism of $\mathbf{L} 1$ to attenuate CORT-induced cell apoptosis is through the adjustment of both caspase-3 and Bcl-2 proteins. Like GA, both nNOS and eNOS might be involved in
\end{abstract}


the neuroprotective mechanism of $\mathbf{L 1}$. All the evidences suggest that $\mathbf{L 1}$ may be a potential agent to treat depression.

Keywords: gardenamide A; amantadine; neuroprotection; nNOS; eNOS; NMDA

\section{Introduction}

Gardenamide A (GA) was firstly isolated from the fruit of Gardenia jasminoides [1], and later was also found in Rothmannia urcelliformis [2], which is a widespread small tree in the forests of East Africa. Previously, our research group has developed a scheme to synthesize GA, and found that GA displayed very good neuroprotective effects to serum deprived- and 6-hydroxydopamine (6-OHDA)- induced impairments in PC12 cells [3]. GA was confirmed as the activators of both neuronal nitric oxide synthase (nNOS) and endothelial nitric oxide synthase (eNOS).

As an ongoing project, we are concerned about the problem of depression. It is well known that corticosterone (CORT) is an important steroid hormone in regulating the metabolism of fat, protein, and glucose in various tissues. High concentrations of glucocorticoids showed adverse effects on the central nervous system (CNS), especially on the hippocampus [4,5]. As a stress hormone, repeated injections of CORT decreased the number of reelin+ cells in the subgranular zone (SGZ) of the adult dentate gyrus in a preclinical animal model of depression [6,7]. This evidence indicated that the decreased SGZ reelin expression could bring about a deficit in granule cell maturation, which could be an important event in the pathophysiology of depression. Interestingly, investigations have shown that hippocampal nNOS mediates the depressogenic effects of chronic stress by down-regulating glucocorticoid receptors and suppressing hippocampal neurogenesis [8,9]. It was also indicated that reelin+ cells within the dentate gyrus contain glucorticoid receptors [10]. Therefore, GA, as an effective nNOS activator, is hypothesized as an effective agent to attenuate CORT-induced impairments.

Preliminary study showed that both GA and amantadine (ATD) provide a mild neuroprotective effect against CORT-induced insults in PC12 cells. ATD, which is a weak NMDA receptor antagonist, is currently applied as an antiviral and an anti-PD drug [11]. The mechanism of ATD in treating nervous system disorders is increasingly confirmed by the inhibition of NMDA responses [12]. It has also been disclosed that the binding of ATD with NMDA accelerates channel closure. This channel regulation is of profound physiological significance because it is responsible for the powerful voltage dependence of postsynaptic $\mathrm{Ca}^{2+}$ influx at excitatory synapses [13]. Another fact is that CORT markedly facilitates $\mathrm{Ca}^{2+}$ influx into the hippocampal neuron leading to neurotoxicity [14]. All these facts taken together suggest that ATD may enhance the neuroprotection of GA against CORT-induced insults. Therefore, in the current investigation, the design and synthesis of two ATD-GA ligands, together with their biology, will be described. 


\section{Results and Discussion}

\subsection{Chemistry}

As outlined in Scheme 1, in the current study, there are two bonding modes between ATD and GA. In the first mode, ATD reacted with $\alpha$-bromoacetyl chloride to form $N$ - $\alpha$-bromoacetyl amantadine (1). The yield was $68.5 \%$. $N$ - $\alpha$-chloroacetyl amantadine was also found as one of the side products. Compound 1 then reacted with GA under the interaction of $n$-butyl lithium ( $n$-BuLi) at room temperature to give L1. The yield was only 37.6\%. This reaction belongs to Williamson ether synthesis. Replacement of $n$-BuLi with NaH did not make the reaction work.

In the second bonding mode, GA firstly reacted with succinic anhydride at room temperature resulted in $O$ - $\beta$-carboxylpropionyl gardenamide A (2) in high yield, which was $89.0 \%$. Then compound 2 coupled with ATD using 1-ethyl-3-(3-dimethylaminopropyl) carbodiimide hydrochloride (EDC $\cdot \mathrm{HCl}$ ) offered $\mathbf{L} 2$. The yield was $40.6 \%$.
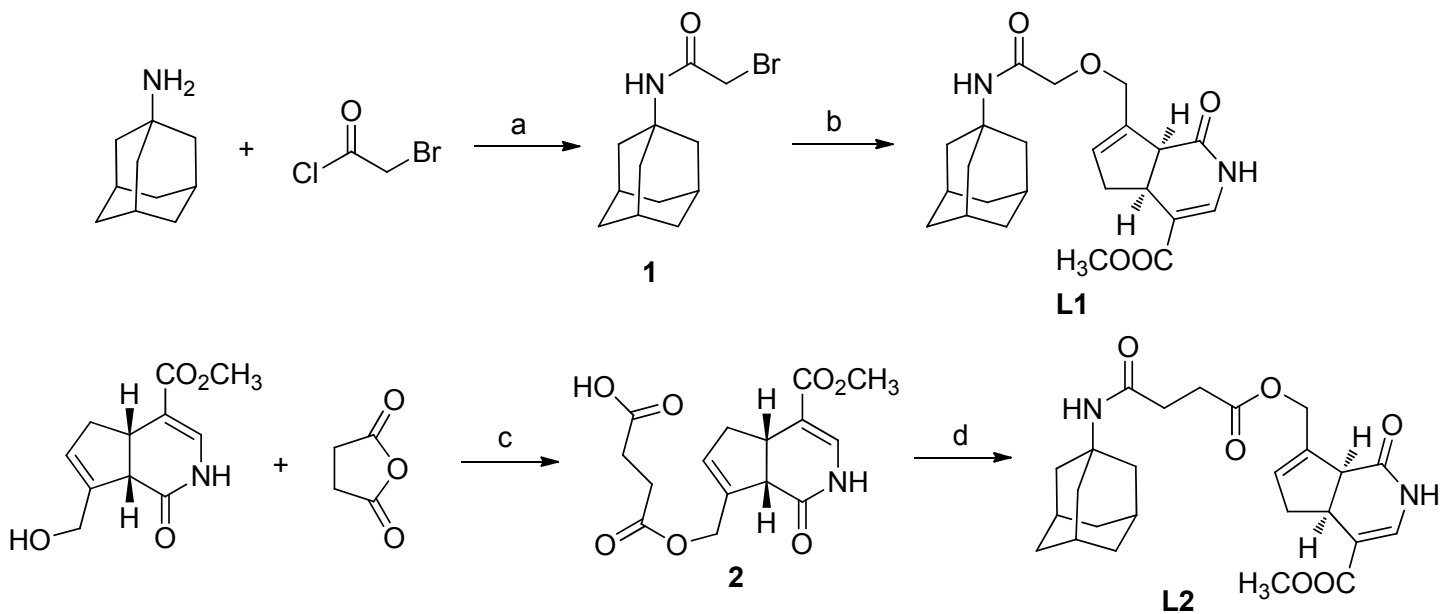

Scheme 1. Synthesis of $\mathbf{L 1}$ and L2. Reagents and conditions: (a) Et $3 \mathrm{~N} / \mathrm{DCM}, 0{ }^{\circ} \mathrm{C} \rightarrow$ r.t., 68.5\%; (b) GA, $n$-BuLi, THF, r.t., 37.6\%; (c) Pyridine, r.t., 89.0\%; (d) EDCI/HOBt/DIPEA, THF, r.t., $40.6 \%$.

\subsection{L1 Showed the Most Active Neuroprotective Effect}

By using MTT assay, the neuroprotective effect against CORT-induced insult in PC12 cells was evaluated. As indicated in Figure 1, all the tested compounds showed the effect to attenuate CORT impairment. At the dose of $30 \mu \mathrm{M}, \mathbf{L 1}$ displayed the most active effect if compared to either ATD or GA, even to the combination of ATD and GA (data not shown). As expected, when ATD bonded to GA in the first mode, it enhanced the neuroprotective effect against CORT impairment in PC12 cells. However, $\mathbf{L} 2$ did not show the enhancing effect. 


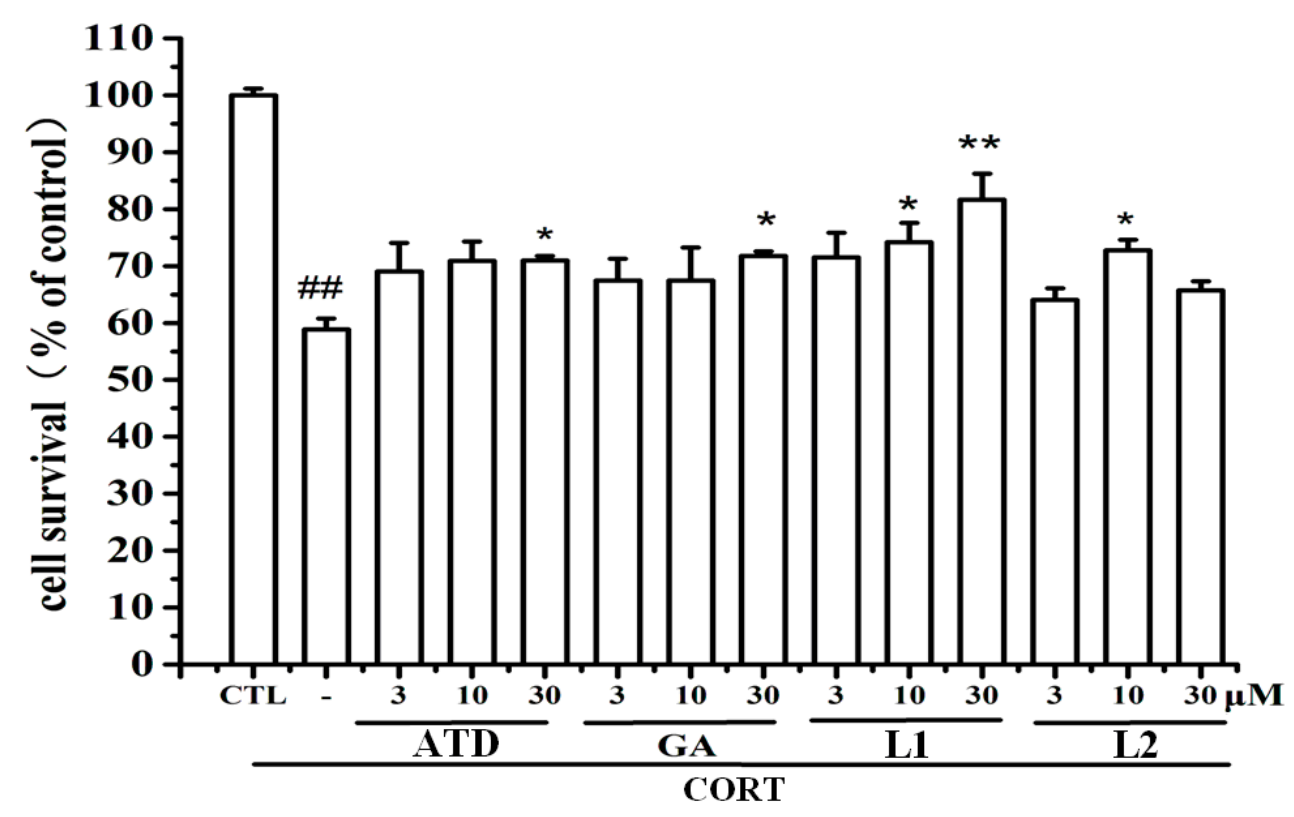

Figure 1. Neuroprotection of amantadine (ATD), gardenamide A (GA), L1 and L2 against CORT-induced toxicity in PC12 cells. PC12 cells were treated with ATD, GA, L1 and L2 (at a dose of 3, 10 and $30 \mu \mathrm{M}$ ), respectively for $2 \mathrm{~h}$ and then incubated with $800 \mu \mathrm{M}$ CORT for another $24 \mathrm{~h}$. Cells viability was determined by MTT assay. ${ }^{\# \#} p<0.01 \mathrm{vs}$. control group; * $p<0.05, * * p<0.01 v s$. CORT group $(n=6)$.

From a view point of chemical structure, in L1, ATD bonded to GA in a more compacted and stable mode; in L2, ATD bonded to GA in a more spacious and non-stable mode, where the ester bond is easily hydrolyzed. It is likely that the compacted stable array between ATD and GA enhance the binding affinity to nNOS, eNOS, or NMDA.

\subsection{L1 Dose-Dependently Attenuated the Increase of ROS Caused by CORT}

CORT is a stress hormone. Overexposure to CORT may induces an oxidative and inflammatory status in the brain accompanied by decreased antioxidant defenses, lipid peroxidation, DNA damage, mitochondrial dysfunction, and abnormalities in the monoaminergic systems. This status also reduced neurogenesis and neuronal plasticity [15,16]. Interestingly, L1 dose-dependently attenuated the CORT-induced generation of reactive oxygen species (ROS) (Figure 2A,B). At the dose of $30 \mu \mathrm{M}, \mathbf{L 1}$ lowered down ROS level from $200 \% \pm 2.1 \%$ to $90 \% \pm 1.8 \%$. This function may attribute to GA scaffold in the structure, which was ever reported as an antioxidant against ROS increase caused by serum deprivation [17]. The evidence implies that the incorporation of ATD into GA by the first bonding mode does not affect its activity as antioxidant. 
A
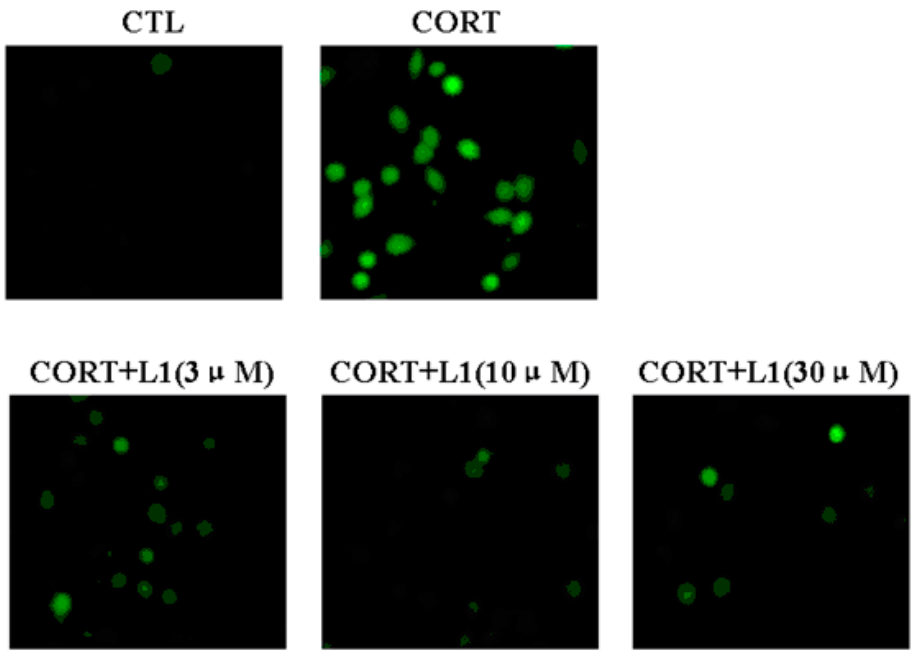

B

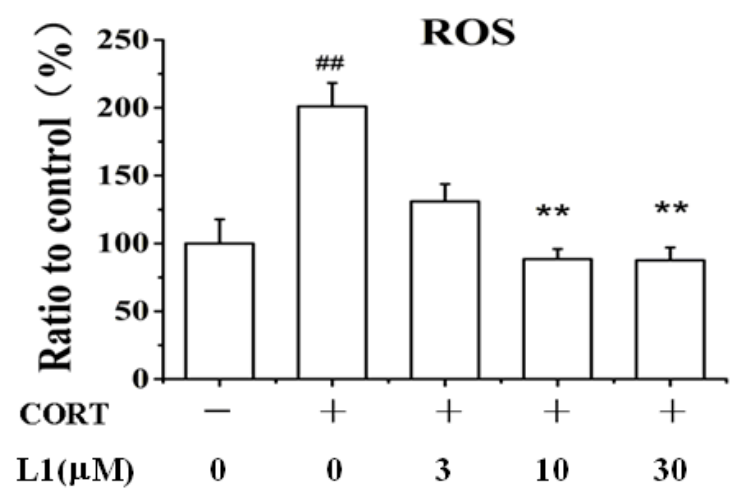

Figure 2. L1 inhibited CORT-induced ROS production. (A) Representative images taken by a fluorescence microscope. The images shown were representative of three experiments; (B) Histogram showing the ROS level in PC12 cells. PC12 cells were pretreated with or without $\mathbf{L 1}$ for $2 \mathrm{~h}$ (at dose of 3, 10 and $30 \mu \mathrm{M}$, respectively), and then treated with or without $800 \mu \mathrm{M}$ CORT for 24 h. ${ }^{* *} p<0.01$ vs. control group; ${ }^{\#} p<0.01 v s$. CORT-treated group $(n=6)$.

\subsection{L1 Reduced CORT-Induced Cell Morphological Change and Apoptosis}

In brain, ROS generated by glucocorticoid exposure will finally induce apoptotic neuronal cell death, which appears to be a key mechanism for the development of depression $[15,18]$. In the current study, treatment of CORT ( $800 \mu \mathrm{M}$ for $24 \mathrm{~h}$ ) increased ROS level (Figure 2A). This intracellular ROS at last resulted in changing cell morphological and apoptosis (Figure 3A,B). It was clearly shown in the first row of Figure $3 \mathrm{~A}$ that after CORT treatment $(800 \mu \mathrm{M}$ for $24 \mathrm{~h})$, the number of cells and neurite decreased; the cells became small, condensed, and smooth; the ability of cellular adherent was weakened. Fortunately, L1 dose-dependently restored the cell morphology to the state that is close to the controlled group (Figure 3A, second row). These morphological changes were indicative of cell apoptosis.

As shown in the first row of Figure 3B, basal apoptosis amounted to $1.18 \%$, CORT treatment $(800 \mu \mathrm{M}$ for $24 \mathrm{~h}$ ) increased apoptosis to $7.31 \%$. L1 reduced the CORT-induced apoptosis to $5.06 \%$.

It is recognized that ATD could alleviate the dopaminergic neuronal apoptosis following traumatic brain injury (TBI) in the substantia nigra (SN) [19]; while GA displayed the activity to attenuate 
apoptosis induced by serum deprivation in PC12 cells [17]. Therefore, it is reasonable to deduce that the function of $\mathbf{L 1}$ to reduce CORT-induced apoptosis in PC12 cells may ascribe to both ATD and GA scaffolds within the molecule.

A
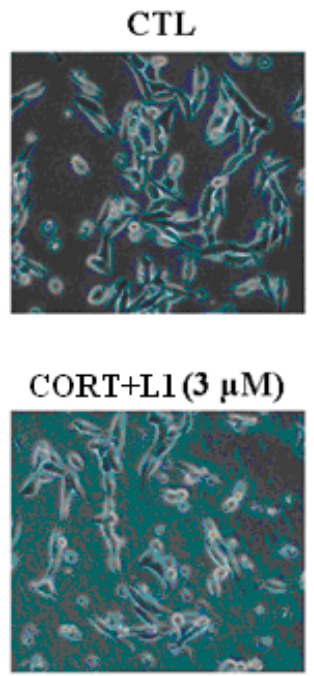

B

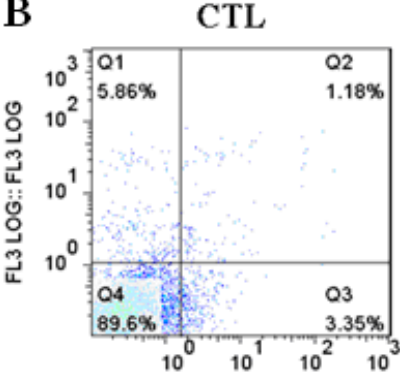

FL1 LOG:: FL1 LOG

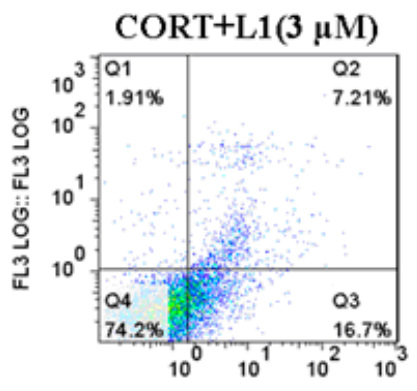

FL1 LOG:: FL1 LOG

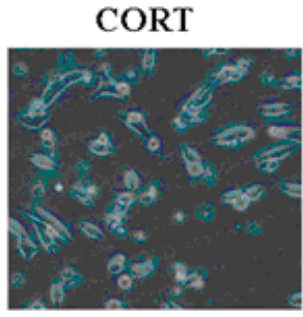

CORT+L1 (10 $\mu \mathrm{M}) \quad$ CORT+L1 $(30 \mu \mathrm{M})$
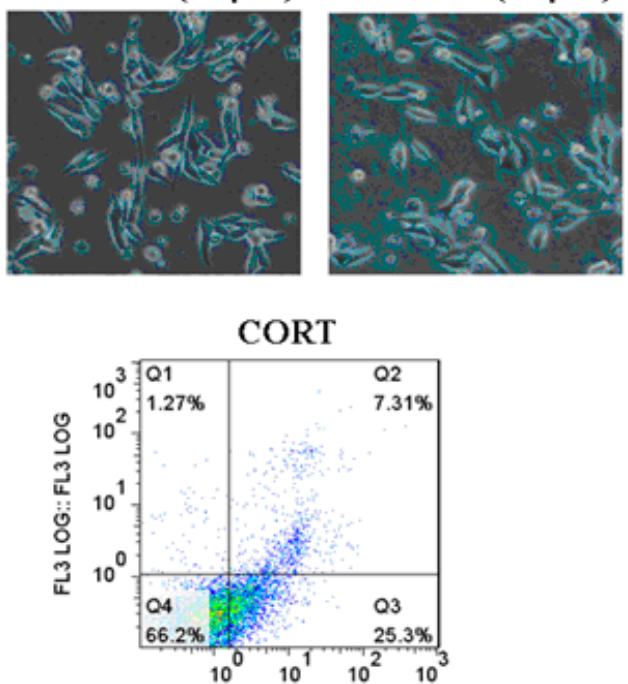

FL1 LOG:: FL1 LOG

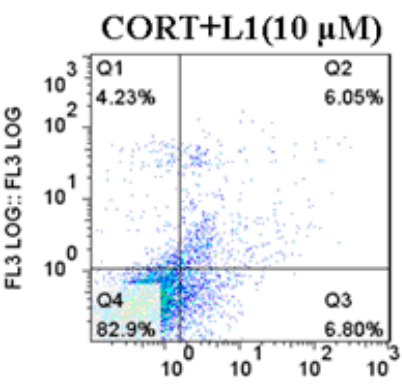

FL1 LOG:: FL1 LOG

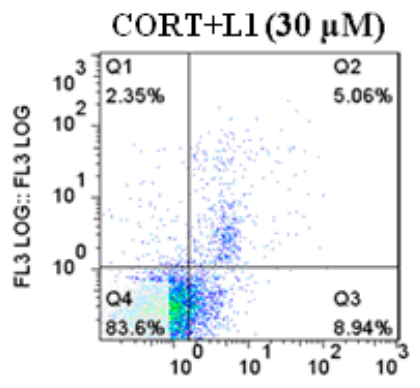

FL1 LOG: FL1 LOG

Figure 3. L1 inhibited CORT-induced morphologic changes and apoptosis in PC12 cells. (A) L1 restored CORT-induced morphologic changes. Representative images were taken by a fluorescence microscope. PC12 cells were pretreated with or without L1 for $2 \mathrm{~h}$ (at dose of 3, 10 and $30 \mu \mathrm{M}$, respectively) and then treated with or without $800 \mu \mathrm{M}$ CORT for $24 \mathrm{~h}$. Cell morphology was significantly damaged by CORT exposure, which was markedly attenuated by F1. The images shown were representative of three experiments; (B) Representative scatter diagrams. $X$-axis: The intensity of Annexin V-PE; $Y$-axis: The intensity of Annexin V-PE. PC12 cells were pre-treated with $\mathbf{L 1}$ for $2 \mathrm{~h}$ (at dose of 3, 10 and $30 \mu \mathrm{M}$, respectively) before the treatment of $800 \mu \mathrm{M}$ CORT for another $24 \mathrm{~h}$. Cells were stained with Annexin-V and PI. The apoptosis of PC12 was detected by flow cytometry. 


\subsection{L1 Increased Caspase-3 (35 kDa) Level and Decreased Cleaved Caspase-3 (19 kDa) Level}

In order to disclose how $\mathbf{L 1}$ attenuate CORT-induced apoptosis, we examined the expression level of caspase-3 and cleaved caspase- 3 by Western Blot. We found that CORT decreased the level of caspase-3 (35 kDa, $\mathrm{kDa}$ : kilodaltons), while in the mean time increased the expression of cleaved caspase-3 (19 kDa). However, L1 reversed the CORT-induced effects to both caspase-3 and cleaved caspase-3 (Figure 4). No doubt, caspase-3 was involved in the apoptotic process, where it is responsible for chromatin condensation and DNA fragmentation [20]. The fact is that CORT treatment made caspase-3 cleave into 19 and 16 kDa subunits, which induced cell apoptosis; While L1 inhibited this process.
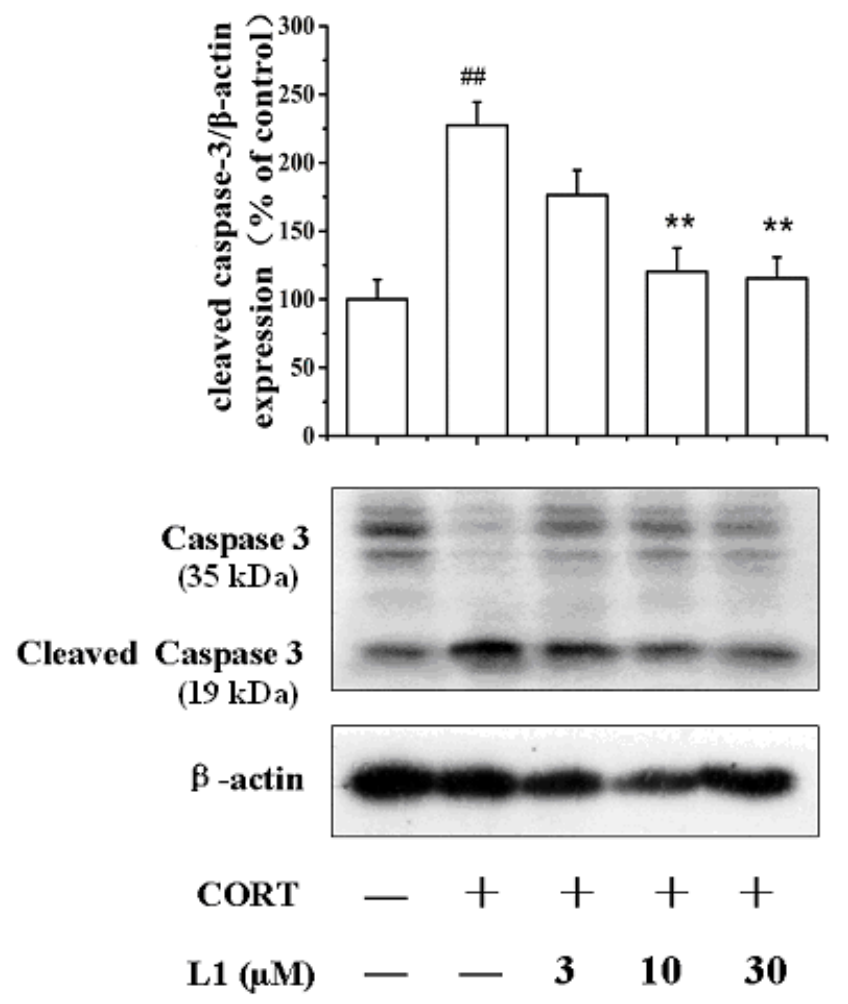

Figure 4. Effect of L1 on caspase-3 (35 kDa) and cleaved caspase-3 (19 kDa). kDa: kilodaltons. PC12 cells were treated with $\mathbf{L 1}(10 \mu \mathrm{M})$ for $2 \mathrm{~h}$ before exposed to CORT $(800 \mu \mathrm{M})$ for $24 \mathrm{~h}$. The levels of caspase-3 and cleaved caspase-3 expression were measured using Western Blot. The density of each lane was presented as mean \pm standard deviation for at least three individual experiments. ${ }^{\#} p<0.01$ vs. control group; $* * p<0.01$ vs. CORT pretreated group. Blots were quantified using Image J software.

\subsection{L1 Restored CORT-Inhibited Bcl-2 Expression}

Another apoptosis-related protein is the B-cell lymphona 2 (Bcl-2). Bcl-2 is specifically considered as an important anti-apoptotic protein and is thus classified as an oncogene [21,22]. As shown in Figure 5, CORT treatment ( $800 \mu \mathrm{M}$ for $24 \mathrm{~h}$ ) lowered down Bcl-2 expression. However, L1 recovered the CORT-inhibited Bcl-2 level. As far as we know, no reports have been displayed that either ATD or 
GA can activate the expression of Bcl-2. Whether this is the synergic effect between ATD and GA requires further investigation.

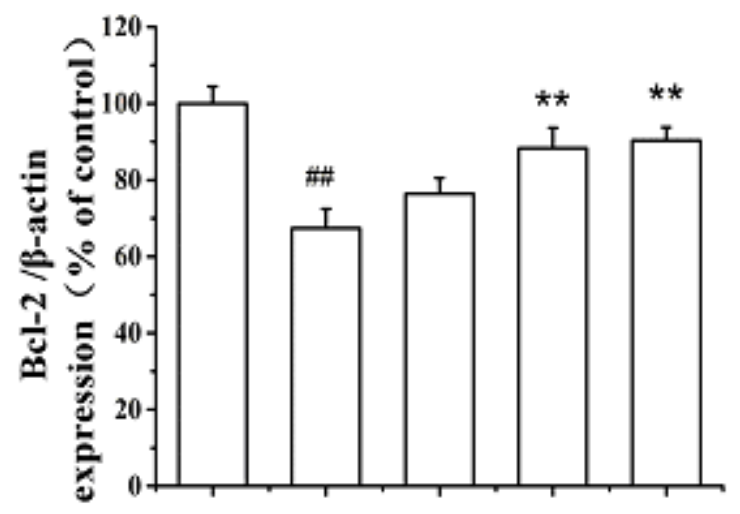

\section{Bcl-2}
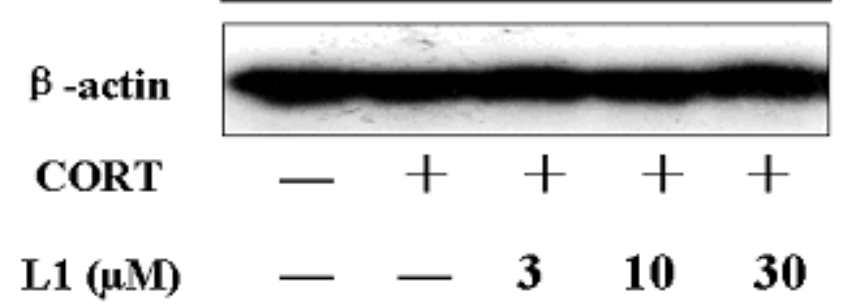

Figure 5. Effect of $\mathbf{L 1}$ on Bcl-2. PC12 cells were treated with $\mathbf{L 1}(10 \mu \mathrm{M})$ for $2 \mathrm{~h}$ before exposed to CORT $(800 \mu \mathrm{M})$ for $24 \mathrm{~h}$. The expression level of Bcl-2 was measured using Western Blot. The density of each lane was presented as mean \pm standard deviation for at least three individual experiments. ${ }^{\#} p<0.01 v s$ control group; $* * p<0.01 v s$ CORT pretreated group. Blots were quantified using Image $\mathrm{J}$ software.

\section{7. nNOS and eNOS might Involve in the Neuroprotection of $\boldsymbol{L} \boldsymbol{1}$}

As reported previously, GA is the activators of both nNOS and eNOS [3]. In the present investigation, it was shown in Figure 6 that both nNOS and eNOS were involved in the neuroprotective effect of $\mathbf{L 1}$ against CORT insults. This was indicated by the fact that either the nNOS specific inhibitor 7-nitroindazole (7-NI), or the eNOS specific inhibitor N5-(1-Imino-3-butenyl)-L-ornithine (L-NIO), inhibited the neuroprotective effect of $\mathbf{L 1}$ against CORT-induced insults. Therefore, it is likely that both nNOS and eNOS might be involved in the neuroprotective effect of L1. The bonding of ATD with GA in the first mode makes $\mathbf{L} 1$ still have the similar functions as GA.

In depressed patients, hippocampal NOS expression is significantly increased [23]. Interestingly, it was found that the non-selective NOS inhibitor, $\mathrm{L}-N^{\mathrm{G}}$-nitroarginine methyl ester (L-NAME), and the nNOS selective inhibitor 7-NI, induce dose-dependent antidepressant-like effects in the forced swimming test [24-26]. Another report showed that the clinical antidepressant Fluoxetine raises brain eNOS expression in the arginine depressive rat model [27]. 


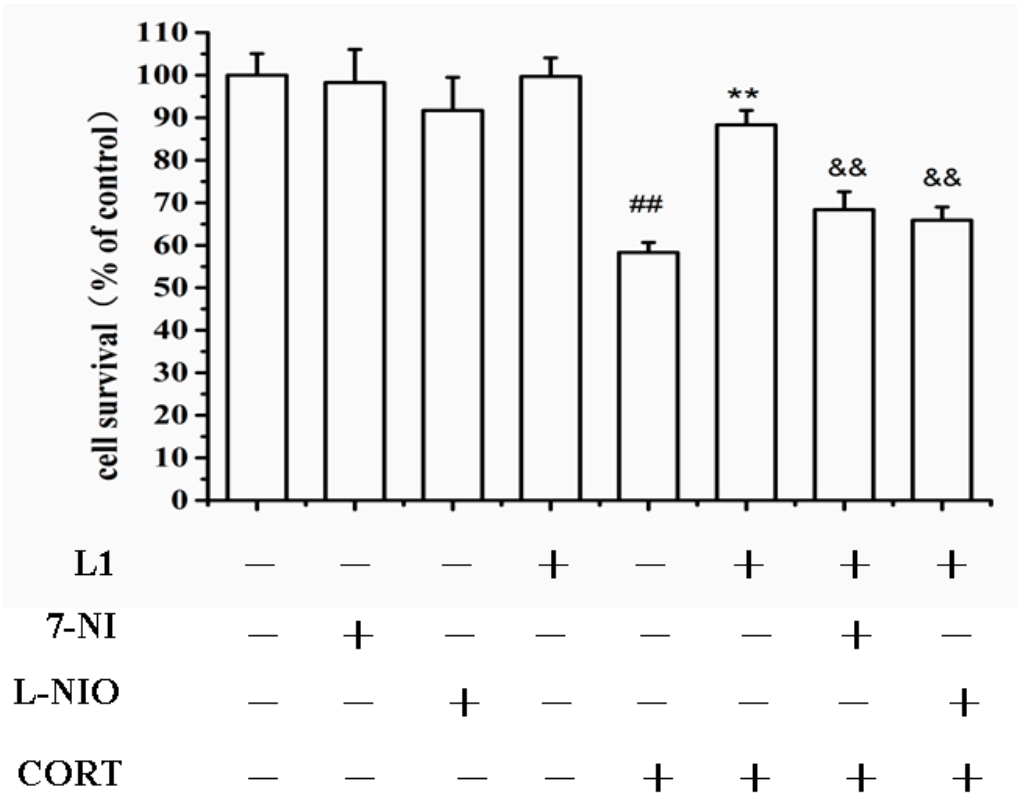

Figure 6. Neuroprotection of $\mathbf{L 1}$ was inhibited by 7-NI and L-NIO. PC12 cells were pretreated with 7-NI $(50 \mu \mathrm{M})$, and L-NIO $(100 \mu \mathrm{M})$ for $30 \mathrm{~min}$ before the treatment of $\mathbf{L 1}(30 \mu \mathrm{M})$ for $2 \mathrm{~h}$, and then incubated with CORT $(800 \mu \mathrm{M})$ for another $24 \mathrm{~h}$. 7-NI: 7-nitroindazole; L-NIO: N5-(1-imino-3-butenyl)-L-ornithine. Cells viability were determined by MTT assay. ${ }^{\#} p<0.01$ vs. control group; ** $p<0.01$, \&\& $p<0.01$, vs. CORT group $(n=6)$.

Based on the fact that both nNOS and eNOS might be involved in the neuroprotective mechanism of $\mathbf{L 1}$, it is likely that $\mathbf{L} \mathbf{1}$ may take effect on depression. However, what the exact effects are requires further investigation.

\section{Experimental Section}

\subsection{Materials and Methods}

Genipin was purchased from Chenddu Kangbang Biotechnology Ltd., Chengdu, China; GA was prepared according to our previous report [3]; Amantadine, EDCI were purchased from Aladdin Reagents Ltd, Shanghai, China; Silica gel for column chromatography was purchased from Qingdao Marine Chemicals Inc., Qingdao, China; Differentiated PC12 cells were purchased from Centre of Cells Resource, Shanghai Institute of Life Science, Chinese Academy of Sciences, China. A014 Typed Nitric Oxide Synthase (NOS) Detection Kit was purchased from Nanjing Jiancheng Institute of Bioengineering; Corticosterone (CORT), 3-(4,5-Dimethylthiazol-2-yl)-2,5-diphenyl tetrazolium bromide(MTT), 2,7-dichlorodihydrofluorescin diacetate (DCFH-DA) and DMSO were purchased from Sigma (St. Louis, MO, USA); Trizol from Tiangen Life Sciences, Beijing, China; 7-Nitroindazole and 1400-W from Enzo (New York, NY, USA); L-NIO from Santa Cluz (Dallas, TX, USA); Fetal bovine serum (FBS) and high-glucose Dulbecco's modified Eagle's medium (DMEM), and horse serum were from GIBCO-BRL (Grand Island, NY, USA); BCA protein assay kit was from the Beyotime Institute of Biotechnology (Haimen, China); Annexin V-FITC/PI Apoptosis Detection Kit was from KeyGen 
(Nanjing, China); Anti-caspase-3 antibody, anti-cleaved caspase-3 antibody, anti-Bcl-2 antibody, and anti- $\beta$-actin antibody were purchased from Cell Signaling Technology (Woburn, MA, USA).

NMR spectra were recorded on Bruker AV-300 (Bruker Biospin, Fällanden, Swiss); TMS was used as internal standard. ESI-MS were recorded on Finnigan LCQ Advantage MAX mass spectrometer. HPLC was performed on a LC-100 liquid chromatograph equipped with a tunable LC-100 UV detector (Shanghai Wufeng Inc., Shanghai, China). Pre-coated thin-layer chromatography (TLC) plates (Institute of Yantai Chemical Industry, Yantai, China) were used for TLC. Spots on TLC plates were detected by either a ZF-7A portable UV detector or spraying $\mathrm{KMnO}_{4}$ solution followed subsequent heating. $\mathrm{N}, \mathrm{N}$-dimethylformamide (DMF) was refluxed over $\mathrm{CaH}_{2}$ for $2 \mathrm{~h}$ and redistilled with reduced pressure; Tetrahydrofuran (THF) was dried over sodium thread and then freshly distilled. Dichloromethane (DCM) was dried over $\mathrm{P}_{2} \mathrm{O}_{5}$ for $2 \mathrm{~h}$ and redistilled.

\subsection{Synthesis of $N$ - $\alpha$-Bromoacetyl Amantadine (1)}

Amantadine (151.4 mg, $1.0 \mathrm{mmol}$ ) was dissolved in $5 \mathrm{ml}$ of dried dichloromethane (DCM) following the addition of $\mathrm{Et}_{3} \mathrm{~N}(0.17 \mathrm{~mL}, 1.2 \mathrm{mmol})$. The solution was cooled down with ice-bath. Then, $\alpha$-bromoacetyl chloride $(0.1 \mathrm{~mL}, 1.2 \mathrm{mmol})$ was added via syringe under stirring. The mixture was stirred for $30 \mathrm{~min}$ at $0{ }^{\circ} \mathrm{C}$ following another $3 \mathrm{~h}$ at room temperature. The reaction was terminated by the addition of $20 \mathrm{~mL}$ saturated $\mathrm{NaHCO}_{3}$ solution, in which the $\mathrm{pH}$ value was 9.5 . The mixed solution was extracted with DCM three times $(3 \times 50 \mathrm{~mL})$. All the extracts were combine, and dried over anhydrous $\mathrm{MgSO}_{4}$. After filtration, excess solvent was removed by rotatory evaporation under reduced pressure. The residues were then purified by RP-HPLC (Eluent: methanol/ $\mathrm{H}_{2} \mathrm{O}=70 / 30, V / V$ ) to afford 1 in white solid (198.5 mg, 68.5\%). $\left.{ }^{1} \mathrm{H} \mathrm{NMR} \mathrm{(300} \mathrm{MHz,} \mathrm{CDCl}_{3}\right) \delta: 3.93(\mathrm{~s}, 2 \mathrm{H}), 2.10$

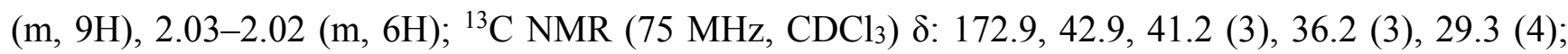
ESI-MS $(\mathrm{m} / \mathrm{z})$ : Calcd for $\mathrm{C}_{12} \mathrm{H}_{19} \mathrm{BrNO} 272.2$, found $272.1[\mathrm{M}+\mathrm{H}]^{+}$.

\subsection{Synthesis of O-(2-(Adamantan-1-ylamino)-2-oxoethyl)gardenamide A (L1)}

Gardenamide A (112.5 mg, $0.5 \mathrm{mmol})$ was dissolved in $5 \mathrm{~mL}$ fresh distilled THF. The solution was cooled down to $0{ }^{\circ} \mathrm{C}$ with ice-bath. Then, $n$-butyl lithium $(65.2 \mathrm{mg}, 1.0 \mathrm{mmol})$ was added. The mixture was stirred for $1 \mathrm{~h}$. Afterwards, solution of compound 1 (138.2 $\mathrm{mg}, 0.5 \mathrm{mmol})$ in $2 \mathrm{~mL}$ fresh distilled THF was added dropwise. The reaction was held at room temperature for another 3 h. $20 \mathrm{~mL}$ of water was added to quench the reaction. The mixture was quickly extracted with DCM for 3 times $(3 \times 50 \mathrm{~mL})$. All the extracts were combine, and dried over anhydrous $\mathrm{MgSO}_{4}$. After filtration, excess solvent was removed by rotatory evaporation under reduced pressure. The residues were then purified by RP-HPLC (Eluent: methanol/ $\left.\mathrm{H}_{2} \mathrm{O}=65 / 35, V / V\right)$ to afford $\mathbf{L 1}$ in slight yellow oil (88.2 $\mathrm{mg}, 37.6 \%$ ). Purity: 97.3\%. ${ }^{1} \mathrm{H}$ NMR (300 MHz, $\left.\mathrm{CDCl}_{3}\right) \delta: 7.21(\mathrm{~s}, 1 \mathrm{H}), 5.83(\mathrm{~s}, 1 \mathrm{H}), 4.34-4.14(\mathrm{q}, J=9.6 \mathrm{~Hz}, 2 \mathrm{H}), 4.03$ $(\mathrm{m}, 2 \mathrm{H}), 3.78\left(\mathrm{~s}, 3 \mathrm{H},-\mathrm{OCH}_{3}\right), 2.97-2.83(\mathrm{~m}, 1 \mathrm{H}), 2.32-2.23(\mathrm{~m}, 1 \mathrm{H}), 2.04(\mathrm{~m}, 3 \mathrm{H}), 1.96-1.94(\mathrm{~d}$, $J=6.0 \mathrm{~Hz}, 6 \mathrm{H}), 1.64(\mathrm{~d}, J=3.5 \mathrm{~Hz}, 6 \mathrm{H}) ;{ }^{13} \mathrm{C} \mathrm{NMR}\left(75 \mathrm{MHz}, \mathrm{CDCl}_{3}\right) \delta: 171.0,166.7,165.6,140.8$, 137.8, 129.7, 111.4, 60.9, 52.5, 51.7, 51.1, 50.1, 41.5 (3), 40.0, 37.5, 36.2 (3), 29.4 (3); ESI-MS (m/z): Calcd for $\mathrm{C}_{23} \mathrm{H}_{31} \mathrm{~N}_{2} \mathrm{O}_{5} 415.2$, found $415.3[\mathrm{M}+\mathrm{H}]^{+}$; HR-MS $(\mathrm{m} / z)$ : Calcd for $\mathrm{C}_{23} \mathrm{H}_{31} \mathrm{~N}_{2} \mathrm{O}_{5} 415.2233$, found $415.2235[\mathrm{M}+\mathrm{H}]^{+}$. 


\subsection{Synthesis of O- $\beta$-Carboxylpropionyl Gardenamide A (2)}

Gardenamide A $(223.2 \mathrm{mg}, 1.0 \mathrm{mmol})$ was dissolved in $5 \mathrm{~mL}$ dried pyridine. Succinic anhydride (200.1 mg, $2.0 \mathrm{mmol}$ ) was added. The mixture was stirred at room temperature for $24 \mathrm{~h}$. Removal of pyridine was carried on by freeze drying. The residues were purified by RP-HPLC (Eluent: methanol $\left./ \mathrm{H}_{2} \mathrm{O}=50 / 50, V / V\right)$ to afford 2 in yellow oil $(287.5 \mathrm{mg}, 89.0 \%) .{ }^{1} \mathrm{H} \mathrm{NMR}\left(300 \mathrm{MHz}, \mathrm{CDCl}_{3}\right)$ $\delta: 7.19(\mathrm{~d}, J=3.9 \mathrm{~Hz}, 1 \mathrm{H}), 5.85(\mathrm{~s}, 1 \mathrm{H}), 4.40-4.30(\mathrm{q}, J=9.6 \mathrm{~Hz}, 2 \mathrm{H}), 3.76\left(\mathrm{~s}, 3 \mathrm{H},-\mathrm{OCH}_{3}\right), 3.68-3.52$ (m, 2H), 2.97-2.91 (dd, $J=8.1,8.1 \mathrm{~Hz}, 1 \mathrm{H}), 2.65-2.63(\mathrm{~m}, 4 \mathrm{H}), 2.28-2.22(\mathrm{dd}, J=6.8,6.8 \mathrm{~Hz}, 1 \mathrm{H})$; ${ }^{13} \mathrm{C} \mathrm{NMR}\left(75 \mathrm{MHz}, \mathrm{CDCl}_{3}\right) \delta: 173.4,172.5,171.4,167.5,142.2,133.9,126.7,109.4,60.4,50.6,39.8$, 39.6, 37.3, 36.9, 29.4; ESI-MS (m/z): Calcd for $\mathrm{NaC}_{15} \mathrm{H}_{17} \mathrm{NO}_{7} 346.3$, found $346.3[\mathrm{M}+\mathrm{Na}]^{+}$.

\subsection{Synthesis of O-(4-(Adamantan-1-ylamino)succinyl Gardenamide A (L2)}

Compound 2 (79.5 mg, $0.25 \mathrm{mmol})$ was dissolved in $2 \mathrm{~mL}$ dried DCM and $2 \mathrm{~mL}$ dried DMF. The solution was cooled with an ice-bath. EDCI (72.3 $\mathrm{mg}, 0.38 \mathrm{mmol})$ and HOBt $(51.3 \mathrm{mg}, 0.38 \mathrm{mmol})$ were added and stirred for $15 \mathrm{~min}$. After addition of DIPEA $(0.09 \mathrm{~mL}, 0.38 \mathrm{mmol})$ via syringe, ATD (38.2 $\mathrm{mg}, 0.25 \mathrm{mmol}$ ) was added. The mixture was lasted at room temperature for $23 \mathrm{~h}$. Then $20 \mathrm{~mL}$ of water was added to quench the reaction. The mixture was extracted with DCM three times $(3 \times 50 \mathrm{~mL})$. All the extracts were combine, and dried over anhydrous $\mathrm{MgSO}_{4}$. After filtration, excess solvent was removed by rotatory evaporation under reduced pressure. The residues were then purified by RP-HPLC (Eluent: methanol/ $\left.\mathrm{H}_{2} \mathrm{O}=70 / 30, V / V\right)$ to afford $\mathbf{L 2}$ in slight yellow oil (44.5 $\mathrm{mg}, 40.6 \%$ ). Purity: 98.2\%. ${ }^{1} \mathrm{H}$ NMR (300 MHz, $\left.\mathrm{CDCl}_{3}\right) \delta$ : 8.21-8.19 (s, 1H, -NH), 7.19 (s, 1H), 5.87 (s, 1H), 4.95 $(\mathrm{m}, 2 \mathrm{H}), 3.73\left(\mathrm{~s}, 3 \mathrm{H},-\mathrm{OCH}_{3}\right), 3.57-3.55(\mathrm{~m}, 2 \mathrm{H}), 2.90-2.87(\mathrm{~m}, 1 \mathrm{H}), 2.67-2.62(\mathrm{~m}, 2 \mathrm{H}), 2.42-2.37$ (m, 2H), 2.19-2.17 (m, 1H), 2.04-2.01 (m, 3H), 1.96-1.95 (m, 6H), 1.66-1.64 (m, 6H); ${ }^{13} \mathrm{C} \mathrm{NMR}$ $\left(75 \mathrm{MHz}, \mathrm{CDCl}_{3}\right) \delta: 172.4,170.6,170.4,167.0,136.8,133.1,133.0,62.9,51.9,52.0,48.0,41.6$ (3), 40.1, 36.3 (3), 32.0, 29.6, 29.4 (3); ESI-MS (m/z): Calcd for $\mathrm{C}_{25} \mathrm{H}_{33} \mathrm{~N}_{2} \mathrm{O}_{6} 457.2$, found $457.3[\mathrm{M}+\mathrm{H}]^{+}$; HR-MS (m/z): Calcd for $\mathrm{C}_{25} \mathrm{H}_{33} \mathrm{~N}_{2} \mathrm{O}_{6} 457.2339$, found 457.2342 $[\mathrm{M}+\mathrm{H}]^{+}$.

\subsection{Culture of PC12 Cells}

Differentiated PC12 cells were cultured in high-glucose Dulbecco's modified Eagle's medium (DMEM) containing 5\% fetal bovine serum (FBS) in 5\% $\mathrm{CO}_{2}$ and a humidified atmosphere of $95 \%$ at $37^{\circ} \mathrm{C}$. The cells were passaged by trypsinization every two to three days. PC12 cells were cultured overnight before use. After washing with DMEM, the cells were plated on 96-well cell culture plate pre-coated with poly-D-lysine and fed with DMEM medium supplemented with $1 \% \mathrm{FBS}, 100 \mathrm{U} / \mathrm{mL}$ of penicillin, and $100 \mu \mathrm{g} / \mathrm{mL}$ of streptomycin in a humidified atmosphere of $95 \%$ and $5 \% \mathrm{CO}_{2}$ at $37{ }^{\circ} \mathrm{C}$ to avoid over cell growth.

\subsection{Neuroprotective Activity Tests}

Differentiated PC12 cells were plated on 96-well cell culture plate. The culture medium was replaced with serum-free medium. Cells in the control group were cultured in the medium with $1 \%$ FBS. Cells in the model group were treated with CORT at $800 \mu \mathrm{M}$; Cells in the other groups were treated with ATD, GA, L1, and $\mathbf{L 2}$ at different doses $(3,10,30 \mu \mathrm{M})$, respectively, for $2 \mathrm{~h}$ before the 
treatment of CORT $(800 \mu \mathrm{M})$ for $24 \mathrm{~h}$. Each experiment was repeated at least three times. After $24 \mathrm{~h}$ treatment, the medium was removed and replaced with $90 \mu \mathrm{L}$ of fresh DMEM. Cell viability was determined by MTT assay as described below.

\subsection{MTT Assay}

Cell viability, virtually the mitochondrial activity of living cells, was measured by a quantitative colorimetric assay with 3-(4,5-Dimethylthiazol-2-yl)-2,5-diphenyl- tetrazolium bromide (MTT). After $24 \mathrm{~h}$ treatment for the control and the drug-treated groups, the culture medium were removed and replaced with $90 \mu \mathrm{L}$ of fresh DMEM. An aliquot $(10 \mu \mathrm{L})$ of $5 \mathrm{mg} / \mathrm{mL}$ MTT in phosphate-buffered saline (PBS) was added to each well. A well added $10 \mu \mathrm{L}$ of $5 \mathrm{mg} / \mathrm{mL}$ MTT and $90 \mu \mathrm{L}$ DMEM was set as negative control. The plates were then incubated at $37{ }^{\circ} \mathrm{C}$ for $4 \mathrm{~h}$, then supernatants were discarded. $100 \mu \mathrm{L}$ of DMSO solutions were added to each wells and the solutions were mixed thoroughly. Then the plates were incubated at $37{ }^{\circ} \mathrm{C}$ for another $10 \mathrm{~min}$. Each sample was mixed again and the resultant formazan was measured by its absorbance at $570 \mathrm{~nm}$ using a BIO-RAD680 plate reader (Thermo, Walsam, MA, USA). The experiments were repeated at least 3 times and compared with the control experiment.

\subsection{Neuroprotective Inhibition Test}

Differentiated PC12 cells were pretreated with 7-NI $(50 \mu \mathrm{M})$ and L-NIO $(100 \mu \mathrm{M})$, for half an hour respectively. Then the cells were treated with $\mathrm{L} 1(30 \mu \mathrm{M})$ for $2 \mathrm{~h}$ before the addition of CORT at a final concentration of $800 \mu \mathrm{M}$. The cells were cultured for another $24 \mathrm{~h}$. The cell viability was tested by MTT assay as described above.

\subsection{Measurement of Intracellular ROS}

ROS generation was evaluated using 2,7-dichlorodihydrofluorescein diacetate (DCFH-DA, Sigma-Aldrich), a radical sensor and membrane-permeable probe that is de-esterified intracellularly. The dye penetrates cells freely and is then hydrolyzed to DCFH by intracellular esterase. The DCFH is then trapped inside the cells. Upon oxidation by ROS, DCFH yields a highly fluorescent product, the dichlorofluorescein (DCF). Treated cells were loaded with DCFH-DA (50 mM final concentration) in DMEM media in dark for $30 \mathrm{~min}$. The cells were rinsed twice with PBS solution and the fluorescence was analyzed using a high content screening system (ArrayScanVTI, Thermo Fisher Scientific, Pittsburgh, PA, USA). The excitation wavelength was set at $488 \mathrm{~nm}$ and the emission wavelength was set at $525 \mathrm{~nm}$.

\subsection{Morphologic Changes}

PC12 cells grown on 48-well plates were treated with $\mathbf{L 1}$ and/or CORT as described above. After that, the medium was removed by washing with PBS. Morphologic changes were observed by phase-contrast microscopy and cells images were taken using a fluorescence microscope (IX71, Olympus, Tokyo, Japan). 


\subsection{Flow Cytometry Analysis for Cell Apoptosis}

The number of viable, early apoptotic, and late apoptotic cells was detected and analyzed by flow cytometry using an annexin V-PE and Propidium Iodide (PI) double staining kit (Biotium, Hayward, CA, USA) in accordance with the manufacturer's instructions. Briefly, cells were collected by centrifugation and resuspended in $100 \mu \mathrm{L}$ of $1 \times$ binding buffer with $5 \mu \mathrm{L}$ annexin V-PE and $5 \mu \mathrm{L}$ PI. After incubation at room temperature for $15 \mathrm{~min}$ in the dark, $200 \mu \mathrm{L}$ of $1 \times$ binding buffer was added. The cells were analyzed using a FACScan and CELLQuest software (Biomedika, QC, Canada). At least 20,000 events per assay well were included and represented as dot plots. Annexin+/PI- cells were considered early apoptotic cells, annexin+/PI+ late apoptotic cells, and annexin-/PI- viable cells. Percentage of apoptosis was calculated based on all the Annexin+/PI- (early apoptotic) plus the annexin + PI+ (late apoptotic) cells.

\subsection{Western Blot}

Cells from different experimental conditions were lysed with ice-cold RIPA lysis buffer as described previously [28]. Protein concentration was measured with a BCA protein assay kit according to the manufacturer's instructions. Samples with equal amounts of proteins were separated on $8 \%$ polyacrylamide gels, then were transferred to PVDF membrane, and probed with selective anti-phospho antibodies against caspase-3 (35 kDa, kDa: kilodaltons), cleaved caspase-3 (Asp175, $19 \mathrm{kDa}$ ), and Bcl-2 (C-terminal, $28 \mathrm{kDa}$ ), respectively. Blots were subsequently stripped from antibodies and re-probed with the respective pan antibody or anti- $\beta$-actin in order to confirm the equal protein loading. Immunoblots shown in the figures correspond to a representative experiment that was repeated four times with similar results.

\subsection{Data Analysis and Statistics}

Statistical analyses were conducted with the software SPSS 13.0 (SPSS Ltd., Chicago, IL, USA). Data are expressed as the mean \pm SEM or mean \pm SD. Variation between groups was analyzed using one-way ANOVA, which was followed by Student-Newman-Keuls or Dunnett's T3 procedures when the assumption of equal variances did not hold. $p$ Value $<0.05$ was considered statistically significant.

\section{Conclusions}

In summary, two ATD- GA ligands have been designed and synthesized. Chemically bonding of ATD with GA through a methylene carbonyl bridge (L1) enhances the neuroprotective effect against CORT-induced insults in PC12 cells; while bonding through succinyl bridge (L2) does not. L1 reduces the level of reactive oxygen species (ROS) and cell apoptosis generated by CORT. It restores CORT-changed cell morphology to a state that is closed to normal PC12 cells. One mechanism of L1 to attenuate CORT-induced apoptosis is through the adjustment of both caspase- 3 and Bcl-2 proteins. Both nNOS and eNOS might involve in the neuroprotective mechanism of L1, which is similar to GA, All the evidences suggest that $\mathbf{L} 1$ might be a potential agent to treat depression. 


\section{Acknowledgments}

This research was financially supported by the National Natural Science Foundation of China (Nos. 81172982, 30670652, 30970935, and 31371088), the Guangdong Provincial Project of Science and Technology (Nos. 2010A030100006 and 2011B050200005), the Natural Science Foundation of Jiangxi Province (No. 20151BAB215030), and the Key Projects of Natural Science Foundation of Jiangxi Province (No. 20151BDH80081).

\section{Author Contributions}

Heru Chen and Wenhua Zheng conceived and designed the experiments. Jiaqiang Zhao, Rikang Wang, Lizhi Peng, Lei Zhang, Jian Yang performed the experiments and analyzed the data. Heru Chen, Rikang Wang, Jiaqiang Zhao, and Lizhi Peng wrote the manuscript. Heru Chen and Wenhua Zheng finally approved the manuscript. All authors read and approved the manuscript.

\section{Conflicts of Interest}

The authors declare no conflict of interest.

\section{References}

1. Machida, K.; Oyama, K.; Ishii, M.; Kakuda, R.; Yaoita, Y.; Kikuchi, M. Studies of the constituents of Gardenia species. II. Terpenoids from Gardeniae Fructus. Chem. Pharm. Bull. 2000, 48, 746-748.

2. Bringmann, G.; Hamm, A.; Kraus, J.; Ochse, M.; Noureldeen, A.; Jumbam, D. Gardenamide A from Rothmannia. urcelliformis (Rubiaceae.)-Isolation, Absolute Stereostructure, and Biomimetic Synthesis from Genipine. Eur. J. Org. Chem. 2001, 2001, 1983-1987.

3. Luo, J.; Wang, R.; Huang, Z.; Yang, J.; Yao, X.; Chen, H.; Zheng, W. Synthesis of stable genipin derivatives and studies of their neuroprotective activity in PC12 cells. ChemMedChem 2012, 7, 1661-1668.

4. Talmi, M.; Carlier, E.; Soumireu-Mourat, B. Similar effects of aging and coricosterone treatment on mouse hippocampus function. Neurobiol. Aging 1993, 14, 239-244.

5. Hortnagl, H.; Berger, M.L.; Havelec, L.; Hornykiewicz, O. Role of glucocorticoids in the cholinergic degeneration in rat hippocampus induced by ethylcholine aziridinium (AF64A). J. Neurosci. 1993, 13, 2939-2945.

6. Lussier, A.L.; Caruncho, H.J.; Kalynchuk, L.E. Repeated exposure to corticosterone, but not restraint, decreases the number of reelin-positive cells in the adult rat hippocampus. Neurosci. Lett. 2009, 460, 170-174.

7. Lussier, A.L.; Lebedeva, K.; Fenton, E.Y.; Guskjolen, A.; Caruncho, H.J.; Kalynchuk, L.E. The progressive development of depression-like behavior in corticosterone-treated rats is paralleled by slowed granule cell maturation and decreased reelin expression in the adult dentate gyrus. Neuropharmacology 2013, 72, 174-183. 
8. Zhou, Q.G.; Zhu, L.J.; Chen, C.; Wu, H.Y.; Luo, C.X.; Chang, L.; Zhu, D.Y. Hippocampal neuronal nitric oxide Synthase Mediates the Stress-Related Depressive Behaviors of glucocorticoids by downregulating glucocorticoid receptor. J. Neurosci. 2011, 31, 7579-7590.

9. Zhou, Q.G.; Hu, Y.; Hua, Y.; Hu, M.; Luo, C.X.; Han, X.; Zhu, X.J.; Wang, B.; Xu, J.S.; Zhu, D.Y. Neuronal nitric oxide synthase contributes to chronic stress-induced depression by suppressing hippocampal neurogenesis. J. Neurochem. 2007, 103, 1843-1854.

10. Gross, C.M.; Flubacher, A.; Tinnes, S.; Heyer, A.; Scheller, M.; Herpfer, I.; Berger, M.; Frotscher, M.; Lieb, K.; Haas, C.A. Early life stress stimulates hippocampal reelin gene expression in a sex-specific manner: Evidence for corticosterone-mediated action. Hippocampus 2012, 22, 409-420.

11. Blanpied, T.A.; Clarke, R.J.; Johnson, J.W. Amantadine inhibits NMDA receptors by accelerating channel closure during channel block. J. Neurosci. 2005, 25, 3312-3322.

12. Blanchet, P.J.; Metman, L.V.; Chase, T.N. Renaissance of amantadine in the treatment of Parkinson's disease. Adv. Neurol. 2003, 91, 251-257.

13. Dingledine, R.; Borges, K.; Bowie, D.; Traynelis, S.F. The glutamate receptor ion channels. Pharmacol. Rev. 1999, 51, 7-61.

14. Zhou, J.-Z.; Zheng, J.-Q.; Zhang, Y.-X.; Zhou, J.-H. Corticosterone impairs cultured hippocampal neurons and facilitates $\mathrm{Ca}^{2+}$ influx through voltage-dependent $\mathrm{Ca}^{2+}$ channel. Acta Pharmacol. Sin. 2000, 21, 156-160.

15. Leonard, B.; Maes, M. Mechanistic explanations how cell-mediated immune activation, inflammation and oxidative and nitrosative stress pathways and their sequels and concomitants play a role in the pathophysiology of unipolar depression. Neurosci. Biobehav. Rev. 2012, 36, 764-785.

16. Maes, M.; Yirmyia, R.; Noraberg, J.; Brene, S.; Hibbeln, J.; Perini, G.; Kubera, M.; Bob, P.; Lerer, B.; Maj, M. The inflammatory \& neurodegenerative (I \& ND) hypothesis of depression: Leads for future research and new drug developments in depression. Metab. Brain Dis. 2009, 24, 27-53.

17. Wang, R.; Yang, J.; Peng, L.; Zhao, J.; Mu, N.; Huang, J.; Lazarovici, P.; Chen, H.; Zheng, W. Gardenamide A attenuated cell apoptosis induced by serum deprivation via ERK1/2 and PI3K/Akt signaling pathways. Neuroscience 2014, 286, 242-250.

18. Gold, P.W.; Machado-Vieira, R.; Pavlatou, M.G. Clinical and biochemical manifestations of depression: relation to the neurobiology of stress. Neural Plast. 2015, doi:10.1155/2015/581976.

19. Tan, L.; Ge, H.; Tang, J.; Fu, C.; Duanmu, W.; Chen, Y.; Hu, R.; Sui, J.; Liu, X.; Feng, H. Amantadine preserves dopamine level and attenuates depression-like behavior induced by traumatic brain injury in rats. Behav. Brain Res. 2015, 279, 274-282.

20. Porter, A.G.; Jänicke, R.U. Emerging roles of caspase-3 in apoptosis. Cell Death Differ. 1999, 6, 99-104.

21. Tsujimoto, Y.; Finger, L.R.; Yunis, J.; Nowell, P.C.; Croce, C.M. The Bcl-2 protein family: Arbiters of cell survival. Science 1984, 226, 1097-1099.

22. Cleary, M.L.; Smith, S.D.; Sklar, J. Cloning and structural analysis of cDNAs for bcl-2 and a hybrid bcl-2/immunoglobulin transcript resulting from the $\mathrm{t}(14 ; 18)$ translocation. Cell 1986, 47 , 19-28.

23. Oliveira, R.M.; Guimarães, F.S.; Deakin, J.F. Expression of neuronal nitric oxide synthase in the hippocampal formation in affective disorders. Braz. J. Med. Biol. Res. 2008, 41, 333-341. 
24. Yildiz, F.; Erden, B.F.; Ulak, G.; Utkan, T.; Gacar, N. Antidepressant-like effect of 7-nitroindazole in the forced swimming test in rats. Psychopharmacology 2000, 149, 41-44.

25. Spiacci, A., Jr.; Kanamaru, F.; Guimarães, F.S.; Oliveira, R.M. Nitric oxide-mediated anxiolytic-like and antidepressant-like effects in animal models of anxiety and depression. Pharmacol. Biochem. Behav. 2008, 88, 247-255.

26. Ferreira, F.R.; Oliveira, A.M.; Dinarte, A.R.; Pinheiro, D.G.; Greene, L.J.; Silva, W.A., Jr.; Joca, S.R.; Guimarães, F.S. Changes in hippocampal gene expression by 7-nitroindazole in rats submitted to forced swimming stress. Genes Brain Behav. 2012, 11, 303-313.

27. Yoshino, Y.; Ochi, S.; Yamazaki, K.; Nakata, S.; Abe, M.; Mori, Y.; Ueno, S. Antidepressant action via the nitric oxide system: A pilot study in an acute depressive model induced by arginin. Neurosci. Lett. 2015, 599, 69-74.

28. Zheng, W.H.; Quirion, R. Glutamate acting on $N$-methyl-D-aspartate receptors attenuates insulin-like growth factor-1 receptor tyrosine phosphorylation and its survival signaling properties in rat hippocampal neurons. J. Biol. Chem. 2009, 284, 855-861.

(C) 2015 by the authors; licensee MDPI, Basel, Switzerland. This article is an open access article distributed under the terms and conditions of the Creative Commons Attribution license (http://creativecommons.org/licenses/by/4.0/). 